\title{
Studies on Utilization of Plastic Mulching in Tillage by Conservation of Energy: An Overview
}

\author{
P.S. Joshi* and S.V. Pathak \\ Department of Farm Machinery and Power Engineering, College of Agril. Engg. \\ and Tech., Dapoli, India \\ *Corresponding author
}

\section{A B S T R A C T}

\begin{tabular}{|l|}
\hline Ke y w o r d s \\
$\begin{array}{l}\text { Energy conservation, } \\
\text { Minimum tillage, } \\
\text { Biodegradable mulch, } \\
\text { Mulching, Application of } \\
\text { plastic mulch }\end{array}$ \\
\hline Article Info \\
\hline $\begin{array}{l}\text { Accepted: } \\
\text { 04 October 2018 } \\
\text { Available Online: } \\
\text { 10 November } 2018\end{array}$ \\
\hline
\end{tabular}

\section{Keywords}

vation,

Mulching, Application of

10 November 2018
Generally, energy conservation and fuel savings are related to the amount of reduction in tillage and may be quite substantial with no-tillage. Less machinery is required for reduced tillage, which contributes to the decrease in overall energy used in the crop production. No-tillage, minimum tillage and mulching have been broadly used in the modern agriculture operations which had showed excellent results in past as well as in present. These techniques have provided obvious benefits of soil and water conservation on sloping farm-land in the hill regions. In order to reduce erosion, weed control and conservation of soil as well as water, biodegradable mulch practices are utilized. There is increasing interest in the use of plastic mulching for vegetable and fruit crops in the agriculture field. Plastic mulches have tremendous effect on growth and yield of different crops. Plastic mulch can be applied on ground by manual and mechanical method. As compared to the manual method, mechanical method is generally adopted to decrease drudgery of labour with accuracy and efficiency of work.

\section{Introduction}

An individual farmer can obtain significant savings through more efficient management of energy in crop production. Production efficiency can be maintained while decreasing fuel requirements through selection of one of the reduced tillage systems or modifying and combining these systems to fit geographical and individual farm situations. Bare soils, associated with conventional tillage, lead to severe soil erosion from both wind and water. In addition to wind and water erosion, conventional tillage can cost growers in soil productivity and poor water use. In contrast, conservation tillage is any system that leaves at least a third of the surface covered with residue after planting (NRCS USDA).

Conservation tillage system is a method in which at least $30 \%$ of soil surface remains covered by crop residues. Minimum and no tillage systems are important methods of conservation tillage. Conservation tillage improves soil and water resources, saves energy and time, and reduces the costs of agricultural products (Afzalinia et al., 2011).

De Vita et al., (2007) found that zero tillage method decreased the evaporation from the 
top soil. Baker et al., (2007) found that conservation tillage had no carbon sequestration advantage compared to the conventional tillage method. Rusu (2005) reported that minimum tillage reduced fuel consumption for 12.4 to 25.3 liter per hectare and power requirement for 23.6 to $42.8 \%$ compared to the conventional tillage method. Liu et al., (2005) reported that zero tillage increased soil bulk density and soil cone index compared to the conventional tillage. Weed population also reduced in the zero tillage method compared to the conventional method. Fabrizzi et al., (2005) evaluated the effect of conservation tillage on the soil temperature, compaction, water content, and crop yield and reported that soil had the higher water retention during the critical growth stage of corn in no-till method.

\section{Conservation tillage}

Conservation tillage practices range from zero tillage (No-till), reduced (minimum) tillage, mulch tillage, ridge tillage to contour tillage. No tillage (NT) involves land cultivation with little or no soil surface disturbance, the only disturbance being during planting while minimum tillage means reduced level of soil manipulation involving ploughing using primary tillage implements.

Conservation tillage has two basic advantages for the grower: conservation of soil, water, and soil organic matter; and reduction of costly inputs while maintaining or improving crop yields and profits. In mulch tillage, the soil is prepared or tilled in such a way that the plant residues or other materials are left to cover the surface to a maximum extent. Ridge tillage involves planting crops in rows either along both sides or on top of the ridges which are prepared at the commencement of the cropping season. When tillage is at right angles to the direction of the slope it is referred to as contour tillage (NRCS USDA).
Minimum tillage farming systems reduce the number of times the land is cultivated, thereby reducing the potential for wind and water erosion. According to Ribera et al., (2004), the use of a minimum tillage farming system conserves soil moisture and reduces fuel, labor, and machinery costs. In addition, a reduction in wind and water erosion provides significant environmental benefits (Ribera et al., 2004).

Chuma (1993) applied mulch ripping, clean ripping, no-till tied ridging and hand hoeing. No-till tied ridging and mulch ripping showed lower total soil loss than the other treatments. Checking the tillage effects five years (measured annually) after the treatments were applied, erosion and penetration resistance were evaluated by determining organic carbon content, percent clay in the upper root zone structural stability, infiltration and soil strength.

Conservation tillage (no till and reduced tillage) practices simultaneously conserve soil and water resources, reduce farm energy and increase or stabilize crop production. Conservation tillage leads to positive changes in the physical, chemical and biological properties of a soil (Bescanca et al., 2006). Soil physical properties that are influenced by conservation tillage include bulk density, infiltration and water retention (Osunbitan et $a l$. , 2004). Improved infiltration of rainwater into the soil increases water availability to plants reduces surface runoff and improves groundwater recharge (Lipiec et al., 2005). Reduced soil cultivation reduces farm energy requirements and overall farming costs as less area has to be tilled (Monzon et al., 2006).

Infiltration and soil evaporation are among the key processes that determine soil water availability to crops in semi-arid agriculture. The presence of crop residue mulch at the soilatmosphere interface has a direct influence on 
infiltration of rainwater into the soil and evaporation from the soil. Mulch cover reduces surface runoff and holds rainwater at the soil surface thereby giving it more time to infiltrate into the soil (Mupangw et al., 2006). Residue management, mulch till practice manages the amount, orientation, and distribution of crop and other plant residue on the soil surface year round while limiting the soil disturbing activities used to grow and harvest crops in systems where the field surface is tilled prior to planting (Anonymous, 2012).

The use of plastic mulch in agriculture has increased dramatically in the last 10 years throughout the world. This increase is due to benefits such as increase in soil temperature, reduced weed pressure, moisture conservation, reduction of certain insect pests, higher crop yields, and more efficient use of soil nutrients. However, disposing of used plastic films, which cause pollution, has led to development of photodegradable and biodegradable mulches (Kasirajan and Ngouajio, 2012).

\section{Limitations of plastic mulch}

Most mulch films are currently produced from petroleum based plastics, usually polyethylene, and causes a considerable waste disposal problem (Halley et al., 2001). Perhaps a major limitation to commercial uses of plastic mulches is the disposal of the plastic film after use, which causes an environmental pollution problem.

Consequently huge portions of these are left on the field with uncontrolled proliferation of landfills near farms or are burnt uncontrollably by some negligent farmers. This situation can contribute to the release of dangerous substances with a negative environmental impact (Briassoulis, 2007). The dramatic increase in production and lack of biodegradability of commercial polymers, particularly commodity plastics used in agriculture and packaging industry, focused public attention on a potentially huge environmental accumulation and pollution problem that could persist for centuries (Albertsson et al., 1987). High costs related to the regular process of gathering and discarding films and the recycling process, plastic films are often discarded in a dump or burned with the subsequent emission of toxic substances.

\section{Biodegradable mulches}

Biodegradable plastics are present today in various sectors of the economy, but only a very limited amount of this is used in agriculture. In 2007 the global biodegradable plastics used in Europe was around 30,000t representing only $0.06 \%$ of the total market (Briassoulis and Dejean, 2010) Mulch tillage includes the uniform spreading of residue on the soil surface, planning the number, sequence, and timing of tillage operations to achieve the prescribed amount of surface residue needed and using planting equipment designed to operate in high residue situations.

This practice benefits soil by increasing organic matter, improving soil tilth and increases productivity as the constant supply of organic material left on the soil surface is decomposed by a healthy population of earth worms and other organisms (Anonymous, 2012). For an environmentally friendly agricultural activity an alternative strategy to the polyethylene-based mulch is to use bio based agricultural raw materials.

Biodegradable materials are decomposed in the soil by the action of microorganisms such as bacteria, fungi and algae. One of the immediate advantages of using biodegradable products is that they can be buried directly in the soil (e.g., together with crop residues) thus no removal from the field is required at the end of crop cycle (Anonymous, 2013). 


\section{Effect of mulching on crop growth}

Polymerized vegetable oil-coated paper mulches can function as effective mulches during the first year of tree growth. Currently, a major barrier to implementation of these mulches is the higher cost (on an area basis) of paper versus polyethylene. This added cost would be, however, offset by eliminating the need for removing and disposing used polyethylene mulch. The use of thinner paper along with coatings, which add more strength and resistance to degradation, could help lower the overall cost into a more competitive range (Shogren and Rousseau, 2005).

Agber et al., (2017) examined the effect of tillage and Mulch practices on maize performance. Mulch treatment proved to be most effective in promoting maize growth, development and yield. Ridge-tillage showed to be most effective and no-tillage was least. Ridge-tillage and mulch was most beneficial while no-tillage and un-mulch were least beneficial in promoting maize growth, performance and yield in Makurdi. Mulch application and ridge tillage is therefore recommended for improved maize growth and yield.

Ashrafuzzaman et al., (2011) concluded that plastic mulches had tremendous effects on the growth, and yield of chilli, and black plastic showed superior performance among the plastic mulches. Black plastic mulch was suppressed the weed growth and thereby, increased the fruits yield. Therefore, the cultivation of chilli using black plastic mulch could bring an ample scope for producing more spices.

Table.1 Yield response to mulching technique

\begin{tabular}{|l|c|c|c|}
\hline Crop & Region & Yield increase (\%) & Reference \\
\hline Tomato & India & $45-50$ & NCPAH 2011 \\
\hline Tomato & U.S. (North Carolina) & 300 & Sanders 2001 \\
\hline Pepper (Chile) & India & $50-60$ & NCPAH 2011 \\
\hline Pepper (Chile) & U.S. (NorthCarolina) & 400 & Sanders 2001 \\
\hline Pepper (Chile) & Chile & 63 & Ashrafuzzaman et al., 2010 \\
\hline
\end{tabular}

Fig.1 Sample of starch-based biodegradable plastic mulch (BioAgri) recovered after six months burial in the field at Knoxville. Photo J. Moore-Kucera

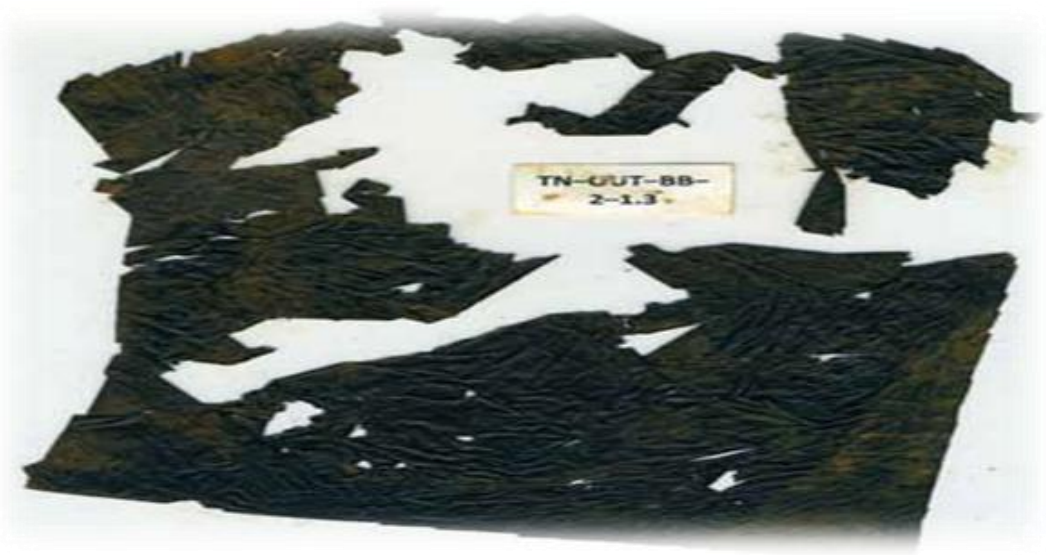


Fig.2 Starch-based biodegradable plastic mulch (BioAgri) in experimental field plots prior to harvest (A), one year later on soil surface (B), and 9 months post incorporation (C). Photos J. Cowan (left) and C. Miles
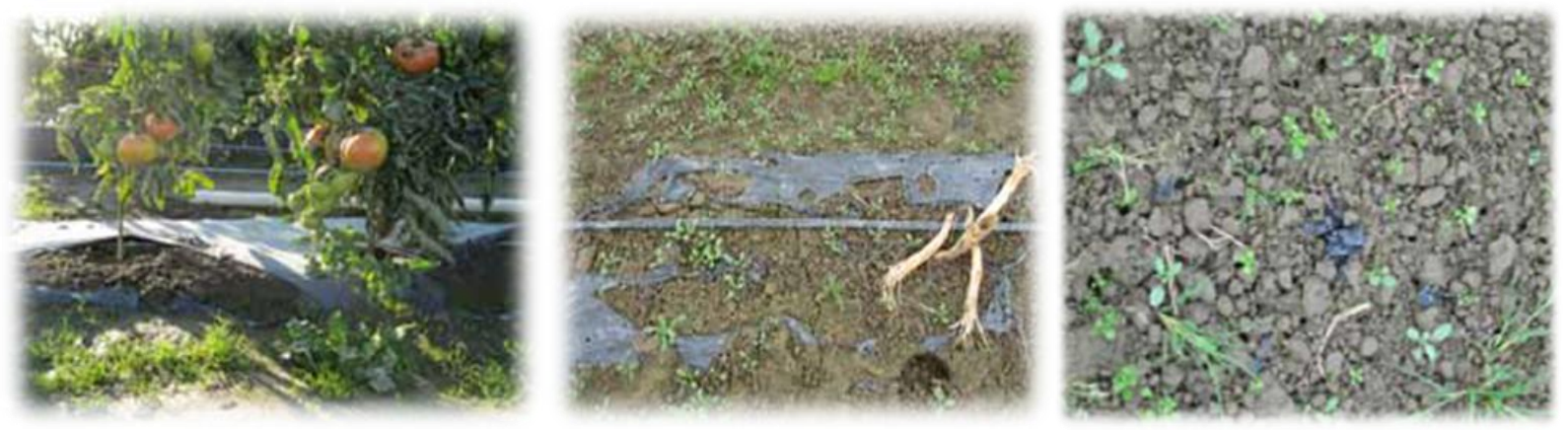

Fig.3a Manual operation of laying mulch film; Fig.3b Mechanical operation of laying mulch film Region wise Plastic Consumption in India
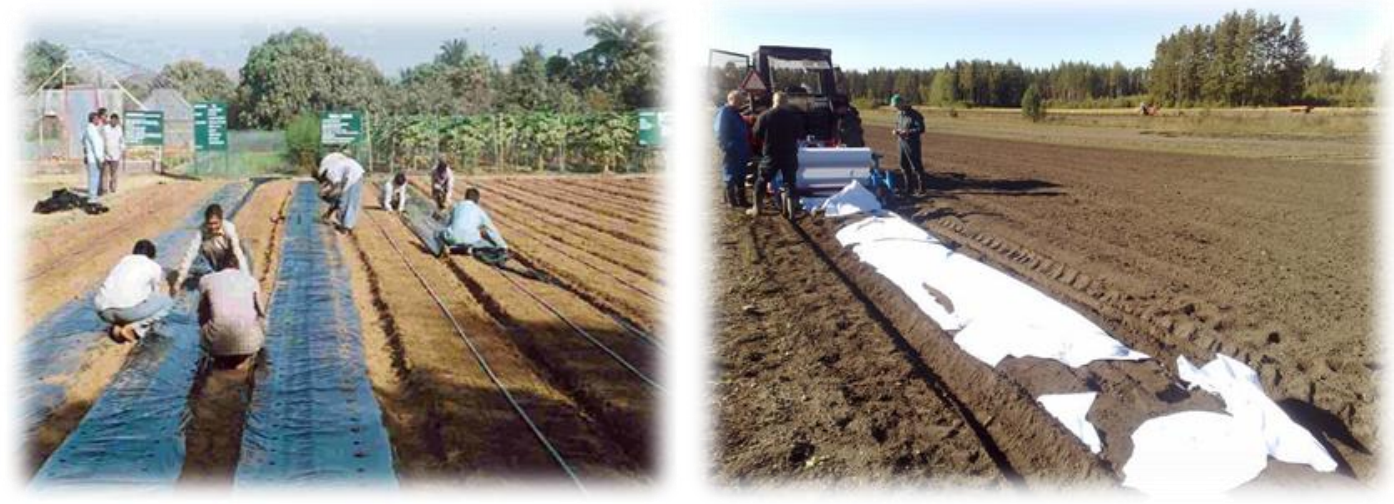

\section{Conservation tillage, 2002-2017}

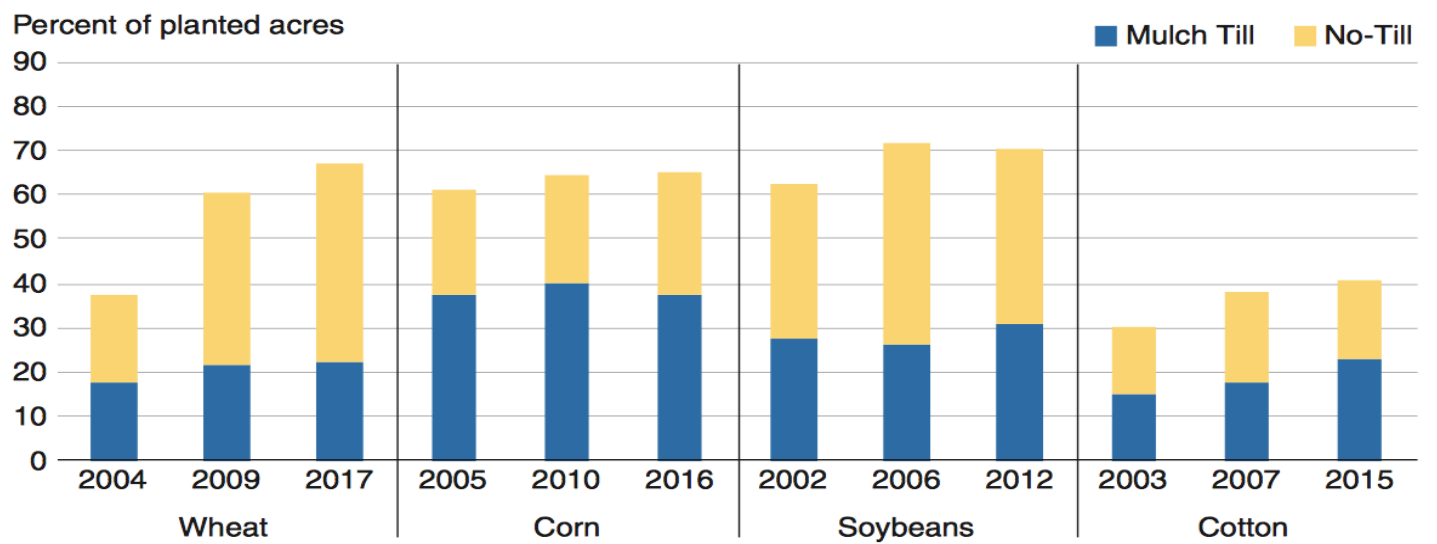

Note: No-till is based on the absence of tillage operations reported in the Agricultural Resource Management Survey (ARMS). Mulch till is indicated when the Soil Tillage Intensity Rating (STIR) is less than or equal to 80 (for the entire season) with some tillage operations.

Source: USDA Agricultural Resource Management Survey data for 2002-2017. 
Fig.4 Figure shows the mulch rate on different tillage systems
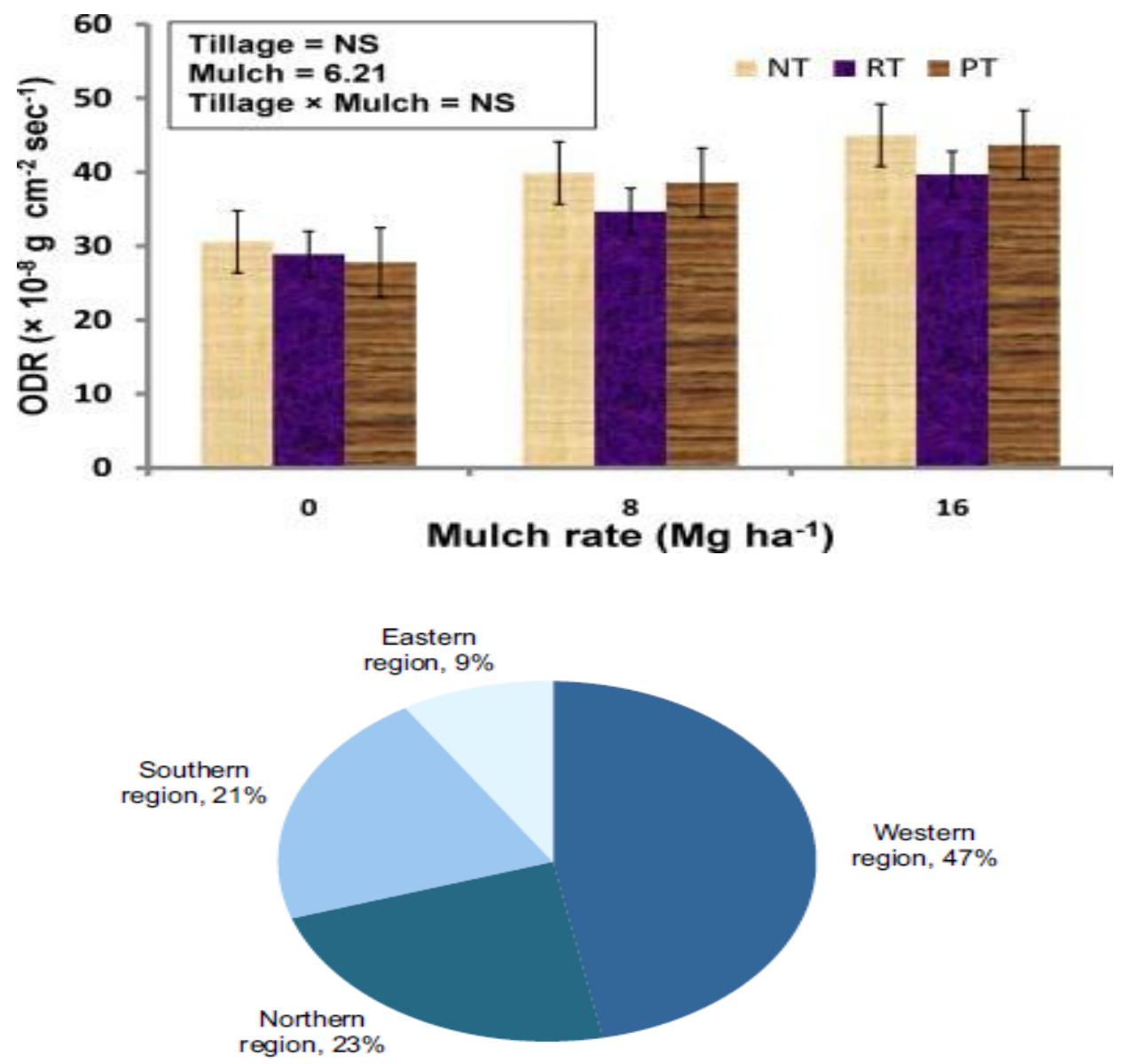

Source: IOCL, Industry reports, Research by Tata Strategic

Fig.5 Percentage share of market mulch film type

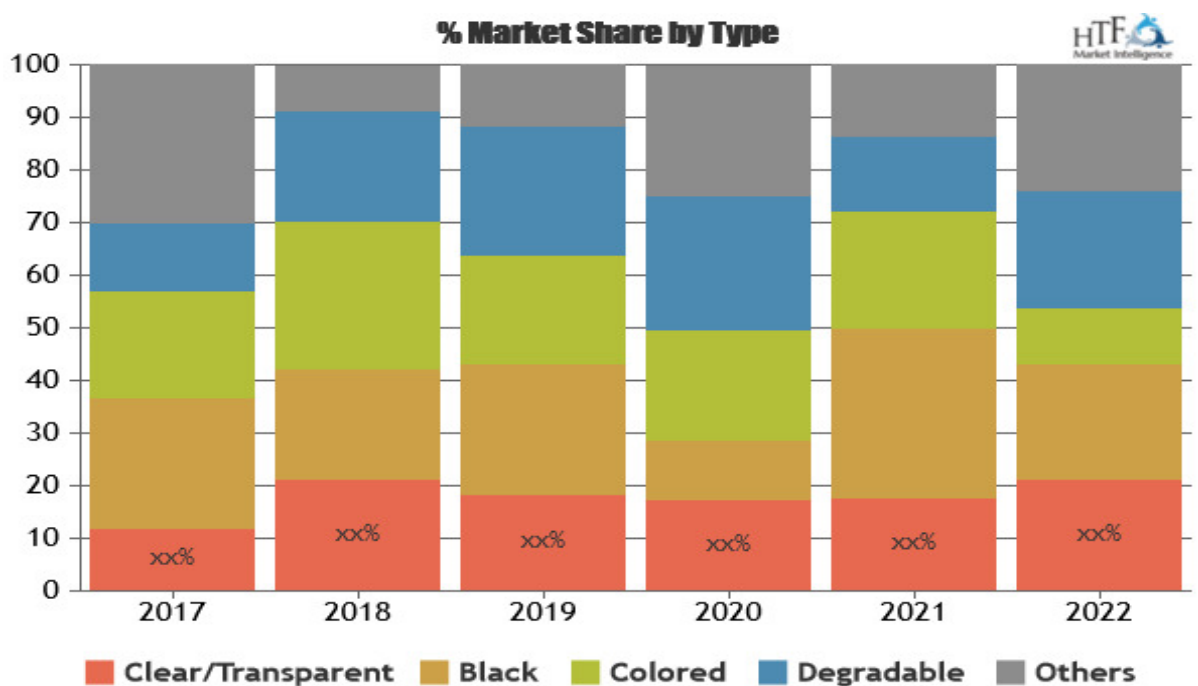


Plastic mulches exercise multiple functions that ultimately lead to higher yields. They improve water and nutrient use by the crops, regulate soil temperature, control weed growth, reduce soil compaction by equipment and people, reduce erosive forces, reduce diseases from splash and reduce rot through contact between plant and soil. Table 1 provides an overview of reported yield increases using the mulch technique.

\section{Applications of plastic mulches on field}

The application of plastic mulching in agriculture, called plasticulture, has increased dramatically throughout the world since 2000 (Kyrikou and Briassoulis, 2007). Plastic is now used in all types of climate, seasons and soils for its numerous benefits, in addition to enhancing soil temperature (Kasirajan and Ngouajio, 2012). Various inorganic mulching materials were applied under different methods such as flat, ridge or ridge furrow and tried with different plastic colors and thicknesses.

Under intensive cropping, timeliness of operations is one of the most important factors which can only be achieved if appropriate use of agricultural machines is advocated (Salokhe and Oida, 2003).

To meet the growing needs of the farmers who wish continuously to improve the profitability of their farming by using more efficient materials and machineries this will be one of the method which will help for improving it. 'Drip irrigation pipe and Mulching paper laying Machine' will be able to do the laying the irrigation pipe as well mulching paper simultaneously (Tipayale, 2017).

Veer et al., (2017) studied about technical solutions like plastic mulching paper. When mulching is practiced along with drip irrigation, it has given the best results. Plastic mulching paper retains soil moisture and prohibits weed growth at the same time it maintains soil temperature. Even though this technology is quite old and versatile, its use in India is still limited due to difficulty of laying the mulching paper manually. This is because of lack of availability of labour and high cost of labour. There are automatic machines but they are either not available in India or the use is limited to large scale farming (Fig. 1-3).

This review paper mainly concerned about different energy conservation techniques used in tillage practices such as conservation tillage, ridge tillage, reduced or minimum tillage, zero tillage, contour tillage, no tillage along with mulch tillage. Mulch tillage has observed very promising results with application of biodegradable mulching with various benefits such as increasing organic matter, improving soil tilth and increases productivity as the constant supply of organic material left on the soil surface is decomposed by a healthy population of earth worms and other organisms. Plastic mulches had tremendous effects on the growth, and yield of different crops. Manual as well as mechanical techniques are available to apply plastic film on ground. But, mainly mechanical techniques are generally preferred as less labour requirement with high accuracy work.

\section{References}

Afzalinia, Sadegh, Alidad. Karami, Mohammad. Hassan. Talati, Shiraz, Iran, (2011) Effect of Conservation Tillage on the Soil Properties and Corn Yield. The Canadian Society for Bioengineering, Paper No. CSBE11204

Agber, P. I., J. Y. Akubo, S. O. I Abagyeh, (2017), Effect of Tillage and Mulch on Growth and Performance of Maize in 
Makurdi, Benue State, Nigeria International Journal of Environment, Agriculture and Biotechnology (IJEAB) Vol-2, Issue-6, Nov-Dec- 2017ISSN: 2456-1878

Albertsson, AC., Andersson, SO., Karlsson, S., (1987). The mechanism of biodegradation of polyethylene. Polym Degrad Stab 18:73-87

Anonymous, 2012Conservation Practice Standard Overview Unites States Department of Agriculture National Resource Conservation Service, NRCS December 2012

Anonymous, 2013 Conservation Tillage, Unites States Department of Agriculture, National Resource Conservation Service, (NRCS)

Ashrafuzzaman, M., M. Halim, Abdul, Mohd Razi, S. M. Ismail, M. Shahidullah and Alamgir Hossain., 2011, Effect of Plastic Mulch on Growth and Yield of Chilli (Capsicum annuum L.). Brazilian Archives of Biology and Technology, 5(2): pp. 321-330

Baker, J. M., T. E. Ochsner, R. T. Venterea and T. J. Griffis. 2007. Tillage and soil carbon sequestration-What do we really know? Agriculture, Ecosystems and Environment 118: 1-5

Bescansa, P., Imaz, M. J., Virto, I., Enrique, A., Hoogmoed, W. B., 2006. Soil water retention as affected by tillage and residue management in semi-arid Spain. Soil and Tillage Research, 87, 19-27

Briassoulis, D., (2007). Analysis of the mechanical and degradation performances of optimized agricultural biodegradable films. Polymer Degradation and Stability 92: 11151132;

Briassoulis, D., Dejean, C., (2010). Critical review of norms and standards for biodegradable agricultural plastics. Part I. Biodegradation in soil. $J$ Polym Environ 18(3): 384-400z
Chuma, E. 1993. Effects of Tillage on Erosion-related Soil Properties of a Sandy Soil in Semi-Arid Zimbabwe. In: Kronen, M. (Ed.). Proceedings of the Fourth Annual Scientific Conference, SADC Land and Water Management Research Programme, SACCAR, Gaborone, Botswana.

De Vita P., E. Di Paolo, G. Fecondo, N. Di Fonzo and M. Pisante. 2007. No-tillage and Conventional Tillage Effects on Durum Wheat Yield, Grain Quality and Soil Moisture Content in Southern Italy. Soil and Tillage Research 92(1-2): 6978.

Halley, P., Rutgers, R., Coombs, S., Kettels, J., Gralton, J., Christie, G., Jenkins, M., Beh, H., Griffin, K., Jayasekara, G., (2001). Developing biodegradable mulch films from starch-based polymers. Starch 53: 362-367;

Kasairajan et al., (2012) Polyethylene and biodegradable mulches for agriculture application, Agron. Sustain. Dev. (2012) 32:501-529

Kyrikou, I. and D. Briassoulis 2007. Biodegradation of agricultural plastic films: A critical review. Journal of Polymers and the Environment 15, 125150. Available online at: http://link. springer.com/article/10.1007\%2Fs1092 4-00700538 (http://link.springer.com/ article/10.1007\%2Fs10924-007-0053-8) (verified 30 April, 2013).

Liu, S., H. Zhang, Q. Dai, H. Huo, Z. K. Xu and H. Ruan. 2005. Effects of Notillage 8 Plus Inter-Planting and Remaining Straw on the Field on Cropland Eco-Environment and Wheat Growth. Ying Yong Sheng Tai XueBao 16(2): 393-396.

Monzon, J. P., Sadras, V. O., Andrade, F. H., 2006. Fallow soil evaporation and water storage as affected by stubble in subhumid (Argentina) and semi-arid 
(Australia) environments. Field Crops Research, 98, 83-90

Mupangwa, Walter., Steve, Twomlow., Sue Walker and Lewis Hove., (2006) Effect of minimum tillage and mulching on maize (Zea mays L.) yield and water content of clayey and sandy soils., ICRISAT.

NCPAH (National Committee on Plasticulture Applications in Horticulture), 2011. Practical Manual on Plastic Mulching. Department of Agriculture, Government of India.

Osunbitan, J.A., Oyedele, D. J., Adekalu, K.O., 2004. Tillage effects on bulky density, hydraulic conductivity and strength of a loamy sand soil in south western Nigeria. Soil and Tillage Research, 82, 57-64.

Ribera, Luis A., F.M. Hons, and James W. Richardson. 2004. Tillage and Cropping Systems. Agronomy Journal. Volume 96. pp. 415424.

Rusu, T. 2005. The Influence of Minimum Tillage Systems upon the Soil Properties, Yield and Energy Efficiency in Some Arable Crops. Journal of Central European Agriculture 6(3):287294.
Salokhe, V.M. and Oida, A. 2003. Development of Appropriate Agricultural Machinery for SoutheastAsian Countries. Laboratory of Agricultural Systems Engineering. Southeast- Asia

Sanders, D.C., 2001. "Using plastic mulches and drip irrigation from vegetable production". Viewed 30 August 2011 at http://www.ces.ncsu.edu/depts/hort/hil/ hil-33. Html

Shogren Randal L., and J. Randall Rousseau 2005. Field testing of paper/polymerized vegetable oil mulches for enhancing growth of eastern cottonwood trees for pulp. Forest Ecology and Management 208 (2005) I 15-122

Tipayale, Amay. Salunke, S. Mayur., U. Samadhan, T. S. T. Thete, and B. T. Sandip., 2017, Advance Mulching Paper Laying Machine. International Journal for Scientific Research \& Development. 5(3): 2321-0613

Veer, V. P and P. R. Thete., 2017, Mulching Paper and Drip Laying Machine. International Journal of Science Technology Management and Research., 2(3): 2456-0006.

\section{How to cite this article:}

Joshi, P.S. and Pathak, S.V. 2018. Studies on Utilization of Plastic Mulching in Tillage by Conservation of Energy: An Overview. Int.J.Curr.Microbiol.App.Sci. 7(11): 47-55. doi: https://doi.org/10.20546/ijcmas.2018.711.008 